\title{
Anti-PLGF Monoclonal Antibody TB-403
}

National Cancer Institute

\section{Source}

National Cancer Institute. Anti-PLGF Monoclonal Antibody TB-403. NCI Thesaurus. Code C78486.

A humanized monoclonal antibody directed ag ainst placental growth factor (PLGF) with potential anti-angiog enic and antineoplastic acivities. Anti-PLGF monoclonal antibody TB403 binds to PLGF, inhibiting the binding of PLGF to the vascular endothelial growth factor receptor, which may result in the inhibition of tumor angiogenesis and tumor cell proliferation. PLGF is a protein that belongs to the family of vascular endothelial growth factors (VEGFs). 